\title{
The determinants of non-audit fees in French firms
}

\author{
Emna Jedidi Hentati ${ }^{\mathrm{a}^{*}}$ and Faouzi Jilani ${ }^{\mathrm{b}}$
}

${ }^{a}$ Doctorate in Faculty of Economic Sciences and Management of Sfax, Tunisia

${ }^{b}$ Professor in Faculty of Economic Sciences and Management of Tunis, Campus Universitaire-Tunis, Tunisia

\section{H R O N I C L E}

\section{Article history:}

Received January 18, 2013

Received in revised format

28 April 2013

Accepted 1 May 2013

Available online

May 12013

Keywords:

Non-audit fees

Corporate governance

Financial performance

\section{A B S T R A C T}

This study analyzes the determinants of non audit-fees for a sample of 67 French companies belonging to the SBF 120 index during the period 2005-2007. Our attention focused on the influence of shareholder / creditor agency costs - namely debts and investment opportunities. Based on panel regression methodology, our results reveal that the affiliation of the auditor to an international network, the presence of an audit committee, the debt, the size of the company and the closing date have an effect on non-audit fees. However, investment opportunities do not affect the amount of non-audit fees.

\section{Introduction}

In recent years, corporate scandals have been multiplied and have shaken the business world (Enron and WorldCom in the United States, OneTel in Australia, Parmalat in Italy, Vivendi in France, etc.). Following these scandals, the realization of non-audit services by audit firms has led to an important academic literature. Indeed, the Commission of Financial Market Operations (COB) introduced in 2002 an obligation requiring the disclosure of the amounts of the auditing fees in all documents and / or prospectus filed or registered from 1st January 2003. The Financial Security Law (LSF) required that all companies make information about the amount of each auditor fees available for stockholders. Besides, the European Directive 2006/43/EC requested the disclosure of the amounts of fees in appendices of the social and consolidated statements.

\footnotetext{
*Corresponding author

E-mail addresses: emna77jedidi@yahoo.fr (E. Jedidi Hentati)

C) 2013 Growing Science Ltd. All rights reserved.

doi: $10.5267 /$ j.msl.2013.05.004
} 
The main objective of these measures is to give investors an overview of the importance of the relationship between the company and its auditors. Indeed, legislators have found that non-audit services put into question the auditors' independence.

The publication of audit and non-audit fees can provide information about the nature of the relationship between auditor and audited firms as well as auditor's independence. Thus, the level of non-audit fees becomes an indicator of the degree of independence of auditors. In this regard, auditors, to signal their independence, choose to reduce consulting services conducted with customers for whom they are already in charge of audit services. On the other side, companies may report a higher quality of their financial information by choosing not to use the non-audit services, signalling therefore the independence of their auditors.

Several researchers (Frankel et al., 2002; DeFond et al. 2002; Reynolds et al. 2004; Hay et al., 2006 Ruddock et al., 2006) have benefited from the availability of the amounts of audit fees to study the potential impact of non-audit services on auditors' independence. However, few studies (Lemaux, 2007) have examined the impact of non-audit fees on the financial performance of the audited company.

In this paper, we will carry out a study of the determinants of non-audit fees to test the hypothesis of a relationship between the financial performance of the audited company and the amount of non-audit fees paid.

The rest of the paper is organized in 4 sections. The first presents an overview of the academic literature on non-audit fees and outlines the hypothesis. The second exposes the research methodology. The third section presents a discussion of our results. The final section concludes.

\section{Literature review and hypothesis}

The literature on the non-audit fees can be divided on three views. The first one examined the impact of non-audit fees on the added value especially on discretionary accruals (Francis \& Ke, 2003; Frankel et al., 2002; Ashbaugh et al., 2003; Reynolds et al., 2004; Lim \& Tan, 2008), on the propensity to issue notices of the continuity (Defond et al., 2002), on the conservatism gains (Ruddock et al., 2005), on the real bonds' estimates (Brandon et al., 2004), on response benefit coefficients (Francis \& Ke, 2006) and on the cases of earnings restatements (Kinney et al., 2004), Bloomfield and Shackman (2008). For the most of these studies, the results suggest that non-audit fees appear to have a negative effect on the audit quality (Defond \& Francis, 2005).

The second view analyzed the effect of non-audit fees on the auditor's independence. Mautz and Sharaf (1961) were the first to study this question. Then, many other authors (DeAngelo, 1981; Beck et al., 1988a, 1988b; Magee \& Tseng, 1990) show that consulting fees reduce auditors' independence. Simunic (1984) and Beck et al. (1988a) find that when the same auditor provides audit and consulting services, it can't be totally independent. Brandon et al. (2004) discuss the effects of the amount of consulting fees on the auditors' independence imposed by bond market. Her results show that the amount of consulting fees is negatively associated with bond ratings. Firth (2002) find that the provision of "Management Advisory Services" MAS, allows the auditor to acquire a specific skill leading to a higher audit quality.

The third view concentrated on the factors which can explain the non-audit fees. The first factor is the presence of a BIG. While Simunic (1980) and Francis (1984) show that BIG 5 has significantly higher fees than other firms, Francis and Stokes (1986), Simon (1985), Palmrose (1986) and CheAhmad Houghton (1996) find opposite results. So, our first hypothesis can be the following: 
Hypothesis 1: The presence of a big has an impact on non-audit fees.

The presence of an audit committee can also have an effect on non audit fees. (Eichenseher et al., 1989) find that the financial market reacts more favourably when a company uses a large audit firm. It also appears that the major audit networks often issue reserves more often than smaller audit firms. As a result, Francis and Wilson (1988), Johnson and Lys (1990) and Firth and Smith (1992) show that companies undergoing high agency costs have a greater tendency to engage in international audit networks. Also, Abbott et al. (2003b) find that the part of consulting fees to total fees decreases in the presence of a fully independent audit committee. They conclude that the role of the audit committee is to control the independence of the auditor by limiting any other non-audit activities. Thus, our second hypothesis can be written as follows:

Hypothesis 2: The presence of an audit committee has a negative impact on non-audit fees.

Another factor mentioned in previous literature is the Debt. Simunic (1980) affirm that the debt which is a measure of the risk of bankruptcy of the client, exposes the auditor to financial risk and reputation. Under these conditions, auditors may provide non-audit missions to help companies to manage their reputation risk. According to Watts and Zimmerman (1986), facing a high level of debt, the company directors encourage their auditors to preserve their accounting image. This should lead to an increase in non-audit fees.

So, our third hypothesis is:

Hypothesis 3: The debt ratio has a positive impact on non-audit fees.

Also, investment opportunities can represent another factor that drives non-audit missions by auditors. Indeed, consulting outside the company can be seen as a way to detect opportunities. In this case, non-audit fees can increase when investment opportunities arise. Thus, our fouth hypothesis can be written as follows:

Hypothesis 4: The investment opportunities have a positive impact on non-audit fees.

The size of the company is also a potentially important determinant of the choice of the external auditor. Most of the empirical studies (Chow, 1982; Copley et al., 1995; Weets, 1999; Abbot \& Parker, 2000; Piot, 2001a, 2001b; Fan \& Wong, 2002a; Niemi \& sundgrem, 2003; Hay \& Work, 2004; Lennox, 2004) have shown a positive relationship between this variable and the amount of fees paid by the audited firm. We assume that this relationship is also verified for non-audit fees. Thus, our fifth hypothesis is the following:

Hypothesis 5: The size of the audited company has a positive impact on non-audit fees.

The closing date is also another determinant of non-audit fees. In fact, the audit activity is not linear and stable during the financial year. There is a high concentration of the activity in the first quarter of the calendar year, period of closure of the accounts of the majority of listed companies. In this perspective, a closing date of accounts at December 31 is a sensitive period for auditors where the demand for auditing increases. So, non-audit fees increase. Thus, our sixth hypothesis can be the following:

Hypothesis 6: A closing date equal to 31 December has a positive impact on non-audit fees.

Apart of the factors indicated, the financial performance can determine non-audit fees. According to Tsui et al. (2001) and Goodwin-Stewart and Kent (2006), leaders of successful companies are more 
likely to report the quality of information provided by an external audit which is more rigorous hence more expensive. We anticipate a positive relationship between this variable and non-audit fees. Thus, our seventh hypothesis is the following:

Hypothesis 7: Financial performance has a positive impact on non-audit fees.

\section{Research methodology}

\subsection{The Sample}

The empirical study focuses on French companies belonging to the SBF 120 index during the period 2005-2007. The data were manually collected from annual reports and documents available on the websites of the companies concerned. From 2003, the French listed companies are required to disclose in their annual reports the amount of fees paid to each of the auditors. We excluded banks, insurance and real estate companies because of their particular accounting presentation and their specific regulations as well as audit firms for which some data were missing. This selection procedure has allowed us to retain 67 companies.

\subsection{Definition and measurement of the variables}

\subsubsection{Non-audit fees}

We use the natural logarithm of non-audit fees which include non audit services and other services.

\subsubsection{Financial performance of the audited company}

We measure the financial performance of the audited company by using the Q of Tobin" which is equal to the sum of Total debt and market value per total assets.

\subsubsection{International membership of the auditor}

The studies of DeAngelo (1981), Piot (2001), Li Dang (2004) and Thoronton et al. (1993) evaluated this variable by referring to the quality of the auditor whether or not he belonged to an international network (Big eight in the eighties which became Big Four today). For the specific needs of our research, we use a dichotomous variable Big / Not Big which takes the value 1 if the firm is audited by at least one Big and 0 otherwise.

\subsubsection{The existence of an Audit Committee}

We measure this variable by using a binary variable which takes the value 1 if there is an audit Committee and 0 otherwise.

\subsubsection{The debt ratio}

According to previous empirical studies (Francis \& Wilson, 1988; Defond, 1992; Firth \& Smith, 1992; Weets, 1999; Abbott \& Packer, 2000; Piot, 2001b; Niemi \& Sundgren, 2003; Piot, 2001; Yeh \& Woidtke, 2005; Minguez-Vera-Martin Ugedo, 2007), we measure shareholders-creditors' agency costs by using the ratio of total debt per total assets. This should reflect the financial risk of the company

\subsubsection{Rate of earnings growth}

According to Kim \& Sorensen, 1986, we adopt the rate of earnings growth as a measure of investment opportunities which can be defined as follows: 


\subsubsection{The size of the company}

OI: $\{$ Earnings (n) - Earnings (n-1)\} / Earnings (n)

The academic literature proposed several measures for the size of the company: the logarithm of the book value of the assets of the company (Taylor \& Baker, 1981; Firth, 1997), the market capitalization (Frankel et al., 2002; Antle et al., 2002; Ashbaugh et al., 2003) and the natural logarithm of total turnover (Haskins and\& Williams, 1988, Chan et al., 1993, Geiger \& Rama, 2003). In our study, we choose to retain this last measurement.

\subsubsection{The Closing date}

We measure this variable by using a binary variable which takes the value 1 if the company closes its audited accounts in December and zero if the company closes its accounts at another date. A summary of these variables is presented in Table 1.

\section{Table 1}

Summary of The variables

\begin{tabular}{|c|c|c|c|c|c|}
\hline \multirow{2}{*}{\multicolumn{2}{|c|}{$\begin{array}{l}\text { Nature Code } \\
\text { Variable to explain :the non-audit fees }\end{array}$}} & Definition & measure & Sign & Source \\
\hline & & Consulting fees & Log (Consulting fees) & & annual \\
\hline \multicolumn{6}{|c|}{ Explanatory variables } \\
\hline \multirow{5}{*}{$\begin{array}{l}\text { Variables of } \\
\text { interest }\end{array}$} & RAUD & Membership & $=1$ if the firm is audited & + & annual \\
\hline & COM AUDIT & the existence of an Audit & $=1$ if there Audit & - & annual \\
\hline & TDTA & the debt ratio & Total debts / total assets & + & Diane base \\
\hline & $\mathrm{OI}$ & growth rate of earnings & Earnings $=\{(\mathrm{n})-$ Earnings & + & Diane base \\
\hline & $\mathrm{Qt}$ & Performance of the & (market value / total & + & Base \\
\hline \multicolumn{6}{|c|}{ Control variables } \\
\hline & Taill & the size of the firm & Natural logarithm of total & + & Diane base \\
\hline & Dec & Closing of accounts & $=1$ if the company & + & Diane base \\
\hline
\end{tabular}

\subsection{The theoretical model}

To verify the validity of our hypothesis, we consider the following theoretical model:

ln_honorna $_{i t}=\alpha_{0}+\alpha_{1}$ raud $_{i t}+\alpha_{2}$ comité-d-audit $_{i t}+\alpha_{3}$ tdta $_{i t}+\alpha_{4}$ oi $_{i t}+\alpha_{5}$ taill $_{i t}+\alpha_{6}$ dec $_{i t}+\alpha_{7} Q t_{i t}+\varepsilon_{i t}$

where:

In_honorna ${ }_{i t}$ : honorarium of "non-audit" of auditors, $\operatorname{raud}_{\mathrm{it}}$ : presence or not of BIG, comité-daudit $_{\text {it : }}$ presence or not of an audit committee, $\operatorname{tdta}_{\text {it }}$ : debts, $\mathrm{oi}_{\text {it }}$ : investment opportunities, taill ${ }_{\text {it }}$ : size of the audited firm, $\operatorname{dec}_{i t}$ : closing accounts, $\mathrm{Qt}_{\mathrm{it}}$ : Tobin $\mathrm{Q}, \mathrm{Qt}_{\mathrm{it}}$ : Tobin $\mathrm{Q}, \mathrm{Qt}_{\mathrm{it}}$ : Tobin $\mathrm{Q}, \mathrm{i}$ : represents the firm, $t$ : period of the study, $\alpha$ : coefficients associated to the independent variables and $\varepsilon_{\text {it }}$ : error term.

\section{Results}

\subsection{Multicolinearity tests}

Firstly, we analyse the independence between the variables using the correlation coefficients given by the Spearman matrix. We retain the critical value of Kervin (0.8) as an indicator of the presence of a multicolinearity problem between variables. We observe that the variables : financial performance of the audited firm "Qt" and debts "tdta" are very correlated with a correlation coefficient of 0,9984 . Then, these variables must not be included simultaneously in the same multivariate model. 
Table 2

Spearman correlation matrix

\begin{tabular}{|c|c|c|c|c|c|c|c|}
\hline & $\mathrm{qt}$ & raud & comité $\sim \mathrm{t}$ & tdta & oi & taill & dec \\
\hline $\mathrm{qt}$ & 1.0000 & & & & & & \\
\hline raud & $\begin{array}{l}-0.1853 \\
0.0113\end{array}$ & 1.0000 & & & & & \\
\hline comité $\mathrm{t}$ & $\begin{array}{l}-0.0129 \\
0.8616\end{array}$ & $\begin{array}{l}0.5578 \\
0.0000\end{array}$ & 1.0000 & & & & \\
\hline tdta & $\begin{array}{l}0.9984 \\
0.0000\end{array}$ & $\begin{array}{r}-0.1865 \\
0.0108\end{array}$ & $\begin{array}{r}-0.0142 \\
0.8472\end{array}$ & 1.0000 & & & \\
\hline oi & $\begin{array}{l}0.1296 \\
0.0780\end{array}$ & $\begin{array}{l}0.0538 \\
0.4655\end{array}$ & $\begin{array}{l}0.0461 \\
0.5324\end{array}$ & $\begin{array}{l}0.1326 \\
0.0711\end{array}$ & 1.0000 & & \\
\hline taill & $\begin{array}{l}0.0096 \\
0.8962\end{array}$ & $\begin{array}{l}0.2482 \\
0.0006\end{array}$ & $\begin{array}{l}0.2181 \\
0.0028\end{array}$ & $\begin{array}{l}0.0206 \\
0.7805\end{array}$ & $\begin{array}{l}-0.0209 \\
0.7766\end{array}$ & 1.0000 & \\
\hline dec & $\begin{array}{l}0.1002 \\
0.1736\end{array}$ & $\begin{array}{l}-0.0801 \\
0.2773 \\
\end{array}$ & $\begin{array}{l}-0.1435 \\
0.0506\end{array}$ & $\begin{array}{l}0.0937 \\
0.2036 \\
\end{array}$ & $\begin{array}{l}0.0476 \\
0.5184 \\
\end{array}$ & $\begin{array}{l}0.2050 \\
0.0050\end{array}$ & 1.0000 \\
\hline
\end{tabular}

Then, we present VIFs and verify that the variables «Qt » and «tdta » present vifs higher than 3. According to Ding and Stolowy (2003), this signals the presence of a multicolinearity problem between these variables and confirms thus the conclusion given by the Spearman correlation matrix.

\section{Table 3}

VIFs of the independent variables

\begin{tabular}{lcccccccc}
\hline Variable & $\mathrm{qt}$ & raud & comité $\mathrm{t}$ & $\mathrm{tdta}$ & oi & taill & dec & Mean \\
\hline VIF & 505.60 & 504.25 & 1.56 & 1.55 & 1.52 & 1.13 & 1.02 & 145.23 \\
$1 / \mathrm{VIF}$ & 0.001978 & 0.001983 & 0.640965 & 0.643091 & 0.657112 & 0.887336 & 0.979221 & \\
\hline
\end{tabular}

\subsection{Results}

To analyse the relationship between the " honorarium of non audit » and the performance of the firm, we consider two models to take into account the multicolinearity problem between the variables ("Qt" et " tdta"). These models can be written as follows:

Model 1:

ln_honorna ${ }_{\text {it }}=\alpha_{0}+\alpha_{1}$ raud $_{i t}+\alpha_{2}$ comité-d-audit $_{\text {it }}+\alpha_{3}$ oi $_{\text {it }}+\alpha_{4}$ taill $_{i t}+\alpha_{5}$ dec $_{i t}+\alpha_{6} \mathrm{Qt}_{\mathrm{it}}+\varepsilon_{\mathrm{it}}$

Model 2:

ln_honorna ${ }_{\text {it }}=\alpha_{0}+\alpha_{1}$ raud $_{\text {it }}+\alpha_{2}$ comité-d-audit $_{\text {it }}+\alpha_{3}$ tdta $_{\text {it }}+\alpha_{4}$ oi $_{\text {it }}+\alpha_{5}$ taill $_{\text {it }}+\alpha_{6}$ dec $_{\text {it }}+\varepsilon_{\text {it }}$

where:

ln_honorna ${ }_{i t}, \mathrm{Qt}_{\mathrm{it}}, \mathrm{raud}_{\mathrm{it}}$, comité-d-audit ${ }_{\mathrm{it}}, \mathrm{tdta}_{\mathrm{it}}, \mathrm{oi}_{\mathrm{it}}, \mathrm{taill}_{\mathrm{it}}, \mathrm{dec}_{\mathrm{it}}, \mathrm{i}, \mathrm{t}, \alpha$ and $\varepsilon$ it are the same variables presented above. According to the Hausman test, our model is a fixed effect model. Then, we test the presence of heterosedasticity and autocorrelation problem.

\section{Table 4}

Specification tests

\begin{tabular}{|c|c|c|c|}
\hline & Chi2 (p-value) & Fisher (p-value) & \\
\hline Fisher test & & $F(61,116)=11.29$ & $\mathrm{P}$-value $=0.0000$ \\
\hline Hausman test & $\mathrm{P}$-value $=0.0000$ & & \\
\hline Breush et Pagan test & $\operatorname{chi} 2(1)=133.59 \quad \mathrm{P}$-value $=0.0000$ & & \\
\hline Wald Modified test & $\operatorname{chi} 2(62)=19266.47 \mathrm{P}$-value $=0.0000$ & & \\
\hline
\end{tabular}


Based on the test of breusch and pagan, we support the presence of heterosedasticity problem between errors. Also, the test of wooldridge indicates that we cannot accept the nul hypothesis of the absence of autocorrelation between errors. The results of the different specification tests are summarized in the Table 4 . The Table 5 below provides the results of the linear regression models.

Table 5

Linear regression of the determinant of non-audit fees

\begin{tabular}{|c|c|c|c|}
\hline & & Model 1 & Model 2 \\
\hline Variables & SP with "non-audit" fees & $\alpha_{i}$ & $\alpha_{i}^{\prime}$ \\
\hline Constant & & -.442129 & -.402536 \\
\hline Raud & & $2.372865 * * *$ & $-1.111475 * * *$ \\
\hline Comité d'audit & & $-1.117381 * * *$ & $.0007691 * * *$ \\
\hline TDTA & & - & $.4663784 * * *$ \\
\hline $\mathrm{OI}$ & & .0014973 & .0014802 \\
\hline taill & & $.350956 * * *$ & $.3485958 * * *$ \\
\hline dec & & .4975759 & $.5029587(0.169)$ \\
\hline Qt & & $.4913372 * * *$ & - \\
\hline \multicolumn{4}{|c|}{ Wald chi $(2)=3429.41 * * * ; \mathbf{R}$-Squared $=0.6319$} \\
\hline \multicolumn{4}{|c|}{ Wald chi $(2)=3344.08^{* * *} ; \mathbf{R}$-Squared $=0.6343$} \\
\hline $\begin{array}{l}\text { Model 1: we elimin } \\
\text { Mode2: we eliminat } \\
\text { Are shown in this ta } \\
\text { Are presented as the } \\
*, * * \text { and } * * * \text { indica } \\
\text { SP corresponds to th }\end{array}$ & $\begin{array}{l}\text { tdta" } \\
\text { t" } \\
\text { s of the linear estimation ( } \alpha \text { it) a } \\
\text { ld chi }(2) \\
\text { evel of } 10 \%, 5 \% \text { and } 1 \% \text { respect }\end{array}$ & $p$-value on each of t & din the template. \\
\hline
\end{tabular}

As it appears from the table, the wald Chi-Square test shows a value of 3429.41 significant at $1 \%$ for Model 1 and 3344.08 significant at $1 \%$ for the model 2 . The results show a high and significant value indicating that the model is significant. This allows us to reject the null hypothesis of nullity of all coefficients $\alpha$. Similarly, the value within, which gives an idea of the share of intra-individual variability of the variable "non-audit fee" explained by those variables, is 63.19\% for Model 1 and 63, $43 \%$ for model 2, which implies a good fit between the groups. Let's start with the membership of the auditor to an international network. The variable "raud" show a significant effect at $10 \%$ level on non-audit fees (which is positive for model 1 and negative for model 2). This is due to the selfselection of the auditors. In fact, having at least one BIG 4 among the two co-auditors results in an increase in fees (premium BIG 4).

For the Audit Committee variable, our results show that the presence of an audit committee has a significant effect at $10 \%$ level for the two models. For the model 1, we assume that the existence of a substitution between governance mechanisms limits the control effort made by external auditors, and therefore reduces audit fees. However, for the model 2, we assume the hypothesis of a complementarity between governance mechanisms. In this sense, an advanced external audit complements the work of an effective internal audit committee, which results in larger fees.

The debt variable which measures the risk of bankruptcy is significant at the $1 \%$ level and indicates a positive effect on non-audit fees. This confirms our third hypothesis. According to Simunic (1980), the debt ratio exposes the auditor to financial and reputational risks. Hence, the auditor has to face these risks by offering consulting services.

The Investment Opportunities variable is not significant. Thus, our fourth hypothesis is rejected.

For the size variable, we report a positive and significant effect at the $1 \%$ level. It is mainly large companies that extend their fees to the achievement of the non- audit missions. Also, the closing date of the accounts explains positively and significantly the amount of paid fees. This result confirms our hypothesis that a date equal to December 31 allows auditors to propose higher non-audit fees because at this date firms' resources are fully employed and therefore auditors require higher non-audit fees. 
Finally, the financial performance of the firm is positively correlated at the $1 \%$ level with not-audit fees. This result confirms our seventh hypothesis. This can be explained by the transfer of auditors' responsibilities by performing non audit services other than audit services.

\section{Conclusion}

We tried to conduct a study of the determinants of non-audit fees, to test the hypothesis of a relationship between the financial performance of the audited company and the amount of non-audit fees. Our results reveal that the membership of the auditor to an international network, the presence of an audit committee, the debt, the size of the company and the closing date influences the amount of non audit fees. Also, we found that non-audit fees increase when the financial performance of the audited company improves. This is explained by the transfer of the auditors' competences by performing non audit services other than audit services. However, investment opportunities do not affect the amount of non audit fees.

\section{References}

Abbot, L.J., \& Parker (2000). Audit committee characteristics and auditor selection. Auditing :A Journal of Practice and Theory, 19(2), 47-66.

Abbott, L.J., Parker S., Peters G.F., \& Raghunandan K. (2003). The association between audit committee characteristics and audit fees. Auditing: A Journal of Practice and Theory 22(2), 17-32.

Antle, R., Gordon, E., Narayanamoorthy, G., \& Zhou, L. (2002). The joint determination of audit fees, nonaudit fees and abnormal accruals. Working paper $n^{\circ} 02-21$, International Center for Finance, Yale Univeristy.

Ashbaugh, H., LaFond, R., \& Mayhew, B. (2003). Do nonaudit services compromise auditor independence? Further evidence. The Accounting review, 78(3), 611-639.

Barkess, L., \& Simnett R. (1994). The provision of other services by auditors: independence and pricing issues. Accounting and Business Research, 24(94), 99-108.

Beck, P., Freka, T., \& Solomon, I. (1988). A model of the market for MAS and audit services: Knowledge spillovers and auditor-auditee bonding. Journal of Accounting Literature, 7, 50-64.

Beck, P., Frecka, T., \& Solomon, I. (1988a). A model of the market for MAS and audit services: Knowledge spillovers and auditor-auditee bonding. Journal of Accounting Literature, 7, 50-64.

Beck, P., Frecka, T., \& Solomon, I. (1988b). An empirical analysis of the relationship between MAS involvement and auditor tenure: Implications for auditor independence. Journal of Accounting Literature, 7, 65-84.

Bloomfield, D., \& Shackman, J. (2008). Non-audit service fees, auditor characteristics and earnings restatements/ Managerial Auditing Journal, 23(2), 125 - 141.

Brandon, D. M., Crabtree, A. D., \& Maher, J. J. (2004). Nonaudit fees, auditor independence, and bond ratings. Auditing: A Journal of Practice \& Theory,23(2), 89-103.

Chan, P., Ezzamel M., \& Gwilliam D. (1993). Determinants of audit fees for quoted UK companies. Journal of Business Finance \& Accounting, 20(6), 765-786.

Che-Ahmad, A., \& Houghton, K. A. (1996). Audit fee premiums of big eight firms: Evidence from the market for medium-size UK auditees. Journal of International Accounting, Auditing and Taxation, 5(1), 53-72.

Chow, C. (1982). The demand for external auditing: size, debt and ownership influences. The Accounting Review, 57(2), 272-291.

Chung, H., \& Kallapur, S. (2001). Client importance, non-audit fees, and abnormal accruals. Working paper, SSRN.

Copley, P.A., Gaver, J.J., \& Gaver, K.M. (1995). Simultaneous estimation of the supply and demand of differentiated audits: evidence from the municipal audit market. Journal of Accounting Research, 33, 137155.

Craswell, A.T. (1999). Does the provision of non-audit services impair auditor independence. International Journal of Auditing, 3, 29-40.

De Angelo, L. (1981a). Auditor size and audit quality. Journal of Accounting and Economics, 3, 183-199.

DeAngelo, L. E. (1981). Auditor independence, 'low balling', and disclosure regulation. Journal of Accounting and Economics, 3(2), 113-127.

DeFond, M. (1992). The association between changes in client firm agency costs and auditor switching. Auditing: A Journal of Practice and Theory, 11 (1), 16-31. 
DeFond, M.L., Raghunandan, K., \& Subramanyam, K.R. (2002). Do nonaudit service fees impair auditor independence? Evidence from going concern opinions. Working paper, University of Southern California.

DeFond, M. L., \& Francis, J. R. (2005). Audit research after Sarbanes-Oxley. Auditing: A Journal of Practice \& Theory, 24, 5-30.

DeFond, M., \& Jiambalvo, J. (1991). Incidence and Circumstances of Accounting Errors. The Accounting Review, 66, 643-655.

DeFond, M., \& Jiambalvo, J. (1993). Factors related to auditor-client disagreements over income-increasing accounting methods. Contemporary Accounting Research, 9, 415-431.

Ding, Y., \& Stolowy, H. (2006). Timeliness and conservatism: Changes over time in the properties of accounting income in France. Review of Accounting and Finance, 5(2), 92-107.

Eichenseher, J.W., \& Shields, D. (1985). Corporate director liability and monitoring preferences. Journal of Accounting \& Public Policy, 13-31.

Ettredge, M., Simon, D., Smith, D., \& Stone, M. (1994). Why do companies purchase timely quarterly reviews?. Journal of Accounting and Economics,18(2), 131-155.

Fan, J.P.H., \& Wong, T.J. (2005). Do external auditors perform a corporate governance role in emerging markets? Evidence from East Asia. Journal of Accounting Research, 43(1), 35-72.

Firth, M., \& Smith, A. (1992). The accuracy of profits forecasts in initial public offering prospectuses. Accounting and Business Research, 22, 239-247.

Firth, M. (1985). An analysis of audit fees and their determinants in New Zealand. Auditing: A Journal of Practice and Theory, 4(2), 23-37.

Firth, M. (1997). The provision of non-audit services and the pricing of audit fees. Journal of Business Finance and Accounting, 24(3/4), 511-525.

Francis, J. R., \& Wilson, E. R. (1988). Auditor changes: A joint test of theories relating to agency costs and auditor differentiation. The Accounting Review, 63(4), 663-682.

Francis, J. (1984). The effect of audit firm size on audit prices: A study of the Australian market. Journal of Accounting and Economics, 6(2), 133-151.

Francis, J., \& Ke, B. (2003). Disclosure of fees paid to auditors and the market valuation of market surprises. Working paper, Pennsylvania State University

Francis, J.R., \& Ke, B. (2006). Disclosure of fees paid to auditors and the market valuation of earnings surprises. Review of Accounting Studies, 11(4), 495-523.

Francis, J., Stokes, D. (1986). Audit prices, product differentiation and scale economies: Further evidence from the Australian market. Journal of Accounting, 24(2), 383-393.

Francis, J., \& Wilson, E. R. (1988). Auditor changes: A joint test of theories relating to agency costs and auditor differentiation. The Accounting Review, 63, 663-682.

Frankel, R., Johnson, M., \& Nelson, K. (2002). The relation between auditors' fees for nonaudit services and earnings management. The Accounting Review, 77, 71-105.

Geiger, M.A., \& Rama, D.V. (2003). Audit fees, non audit fees and auditor reporting on stressed companies. Auditing : A journal of practice \& theory, 22(2), 53-69.

Goodwin-Stewart, J., \& Kent, P. (2006). Relation between external audit fees, audit committee characteristics and internal audit. Accounting \& Finance, 46(3), 387-404.

Haskins, M. E., \& Williams, D. D. (1988). The association between client factors and audit fees: A comparison by country and by firm. Accounting and Business Research, 18, 183-192.

Hay, D., \& Davis, D. (2004). The voluntary choice of an audit of any level of quality. Auditing: A Journal of Practice \& Theory, 23(2), 37-53.

Hay, D.C., Knechel, W.R., \& Wong, N. (2006). Audit fees: A meta-analysis of the effect of supply and demand attributes. Contemporary Accounting Research, 23(1), 141-191.

Iyer, G.S., Iyer, V.M., \& Mishra, B.K. (2003). The impact of non-audit service fee disclosure requirements on audit fee and non-audit service fee in the United Kingdom : an empirical analysis. Advances in Accounting, $20,127-140$.

Johnson, W., \& Lys, T. (1990). The market for audit services : Evidence from voluntary auditor changes. Journal of Accounting and Economics, 12, 281-308.

Kervin, J.B. (1992). Methods for business research. Harpercollins College Div, January 1992.

Kim, W.S., \& Sorensen, E. H. (1986). Evidence on the impact of the agency costs of debt in corporate debt policy. Journal of Financial \& Quantitative Analysis, 21, 131-44. 
Kinney Jr., W. R., Palmrose, Z.-V., \& Scholz, S. (2004). Auditor independence, non-audit services, and restatements: Was the U.S. government right?. Journal of Accounting Research, 42(3), 561-588.

LSF (2003), Loi de Sécurité Financière n ${ }^{\circ}$ 2003-706 du 1er août 2003, Article 109, créant l'article L.820-3 du Code de Commerce, http://www.legifrance.gouv.fr.

Lee, H.Y., \& Mande, V. (2005). The relationship of audit committee characteristics with endogenously determined audit and non-audit fees. Quarterly Journal of Business \& Economics, 44(3/4), 93-112.

Lennox, C. S. (1999a). Non-audit fees, disclosure and audit quality. The European Accounting Review, 8(2), 239-252.

Lennox, C. S. (1999b). Audit quality and auditor size: an evaluation of reputation and deep pockets hypotheses. Journal of Business Finance and Accounting, 26(7-8), 779-805.

Le Maux, J. (2004). Le co-commissariat aux comptes à la française. Revue Française de la Comptabilité, 3438.

Lennox, C. S. (2004). Management ownership and audit firm size : evidence on unlisted companies. Working paper, Hong Kong University of Science and Technology.

Lim, C. Y., \& Tan, P. M. S. (2009). Control divergence, timeliness in loss recognition, and the role of auditor specialization: Evidence from around the world. Journal of Accounting, Auditing \& Finance, 24(2), 295332

Magee, R. P., \& Tseng, M. C. (1990). Audit pricing and independence.Accounting Review, 315-336.

Minguez-Vera, A., \& Martin-Ugedo, J.F. (2007). Does ownership structure affect value? A panel data analysis for the Spanish market. International Review of Financial Analysis, 16, 81- 98.

Mitra, S., Hossein, M., Deis, D.R. (2007). The empirical relationship between ownership characteristics and audit fees. Review of Quantitative Finance and Accounting, 28, 257-285.

Niemi, L., \& sundgrem, S. (2003). Why hire a professional auditor? Evidence on supply and demand for auditor quality from small client segment. Working paper.

Palmrose Z-V. (1986). The effect of nonaudit services on the pricing of audit services: Further evidence. Journal of Accounting Research, 24, 405-411.

Piot, C. (2001a). Agency costs and audit quality: Evidence from France. The European Accounting Review, 10 (3), 461-499.

Piot, C. (2001b). Audit de l'information financière et relations d'agence", Thèse de doctorat en Sciences de gestion, Université Pierre Mendes-France.

Raghunandan, K. (2003). Nonaudit services and shareholder ratification of auditors. Auditing: A Journal of Auditing \& Theory, 23(1), 155-163.

Reynolds, J. K., Deis Jr, D. R., \& Francis, J. R. (2004). Professional service fees and auditor objectivity. Auditing: A Journal of Practice \& Theory, 23(1), 29-52.

Ruddock, C, Hamilton, J., Stokes, D., \& Taylor, S. (2005). Audit partner rotation, earnings quality and earnings conservatism. documents de travail, SSRN

Ruddock, C., Taylor, S.J., \& Taylor, S.L. (2006). Non-audit services and earnings conservatism: Is auditor independence impaired?. Contemporary Accounting Research, 23(3), 701- 746.

Simon, D. (1985). The Audit Services Market: Additional Empirical Evidence. Auditing: A Journal of Practice and Theory, 71-78.

Simunic, D. (1980). The pricing of audit services : Theory and evidence. Journal of Accounting Research, 18, 161-190.

Simunic, D. (1984). Auditing, consulting, and auditor independence. Journal of Accounting Research, 22(2), 679-702.

Taylor, M. E., \& Baker R. L. (1981). An analysis of the external audit fees. Accounting and Business Research, 12, 55-60.

Thornton, D. B., \& Moore, G. (1993). Auditor choice and audit fee determinants.Journal of Business Finance \& Accounting, 20(3), 333-349.

Tsui, J.S.L., Jaggi, B., \& Gul, F.A. (2001). CEO domination, growth opportunities and their impact on audit fees. Journal of Accounting Auditing and Finance, 16(3), 189-208.

Vafeas, N., \& Waegelein, J.F. (2007). The association between audit committees, compensation incentives, and corporate audit fees. Review of Quantitative Finance and Accounting, 28, 241-255.

Watts, R., \& Zimmerman, J. (1986), Positive Accounting theory, Prentice-Hall, Englewood Cliffs, NJ.

Weets, V. (1999). Who will be the new auditor ?. Working paper, Free University of Brussels (VUB).

Yeh, Y. H., \& Woidtke, T. (2005). Commitment or entrenchment?: Controlling shareholders and board composition. Journal of Banking \& Finance, 29(7), 1857-1885. 